\title{
(2) OPEN ACCESS \\ Hypokalaemic periodic paralysis secondary to subclinical hyperthyroidism: an uncommon cause of acute muscle paralysis
}

\author{
Alvin Oliver Payus $\odot,{ }^{1}, 2$ Sat Lin Liew, ${ }^{1}$ Nee Tiong, ${ }^{2}$ Norlaila Mustafa ${ }^{2}$
}

\begin{abstract}
${ }^{1}$ Faculty of Medicine and Health Science, Universiti Malaysia Sabah, Kota Kinabalu, Sabah, Malaysia

${ }^{2}$ Department of Internal Medicine, Universiti Kebangsaan Malaysia Medical Centre, Cheras, Kuala Lumpur, Malaysia
\end{abstract}

Correspondence to Dr Alvin Oliver Payus; dralvinpayus@ums.edu.my

Accepted 6 June 202

Check for updates

(c) BMJ Publishing Group Limited 2021. Re-use permitted under CC BY-NC. No commercial re-use. See rights and permissions. Published by BMJ.

To cite: Payus AO, Liew SL, Tiong $\mathrm{N}$, et al. BMJ Case Rep 2021;14:e240666. doi:10.1136/bcr-2020240666

\section{SUMMARY}

Hypokalaemic periodic paralysis secondary to subclinical hyperthyroidism is an uncommon clinical phenomenon characterised by lower limb paralysis secondary to hypokalaemia in the background of subclinical hyperthyroidism. In this article, we report a patient who presented with progressive lower limb muscle weakness secondary to hypokalaemia that was refractory to potassium replacement therapy. He has no diarrhoea, no reduced appetite and was not taking any medication that can cause potassium wasting. Although he was clinically euthyroid, his thyroid function test revealed subclinical hyperthyroidism. His 24-hour urine potassium level was normal, which makes a rapid transcellular shift of potassium secondary to subclinical hyperthyroidism as the possible cause. He was successfully treated with potassium supplements, non-selective beta-blockers and anti-thyroid medication. This case report aimed to share an uncommon case of hypokalaemic periodic paralysis secondary to subclinical hyperthyroidism, which to our knowledge, only a few has been reported in the literature.

\section{BACKGROUND}

Subclinical hyperthyroidism is defined biochemically as normal level of serum free thyroxine (T4) and triiodothyronine (T3) in the presence of a low thyroid-stimulating hormone level. It usually has no symptoms of hyperthyroidism or only has mild and non-specific symptoms. Here, we report a case of subclinical hyperthyroidism presented with hypokalaemic periodic paralysis (HPP), whereby to our knowledge there have been only very few cases reported in the literature. ${ }^{1}$ This uncommon condition is the centre of discussion in this case report.

\section{CASE PRESENTATION}

A 64-year-old man with an underlying diabetes mellitus type 2, hypertension and erythrodermic psoriasis which is under control with medications presented with progressive bilateral lower limb weakness for 1-week duration. The weakness was extended up to the knee level and caused him difficulty to walk. He denies any numbness, sciatica or lower back pain. There was no preceding history of fall or trauma and no symptoms suggestive of hyperthyroidism. His list of medications includes oral metformin $500 \mathrm{mg}$ once daily, oral losartan $50 \mathrm{mg}$ once daily, oral nifedipine $10 \mathrm{mg}$ three times per day and oral methotrexate $5 \mathrm{mg}$ weekly. He denies taking any over-the-counter nor traditional medication and only drinks alcohol occasionally. On physical examinations, his vital signs showed a low-grade fever with a temperature of $37.7^{\circ} \mathrm{C}$, blood pressure of $148 / 86 \mathrm{~mm} \mathrm{Hg}$, pulse rate of 74 beats/min and respiratory rate of 20 breaths $/ \mathrm{min}$. Examination of the lower limb revealed weakness over the knee and ankle bilaterally with the muscle power of 3 over 5 . The muscle power over the hips and upper limbs was normal. His reflexes were normal, there were no cerebellar signs present, and all his sensory modalities were intact. Examination over the neck region noted there was a diffuse swelling that was more prominent over the right side, which was not tender, firm in consistency, and move upward with swallowing but not with protrusion of the tongue. His abdomen was soft, not tender, and there was no palpable mass or organomegaly. Examinations of the cardiovascular and respiratory systems were normal.

Initial blood investigations were taken and showed marked hypokalaemia. Otherwise, blood $\mathrm{pH}$, random blood glucose, other electrolytes, and renal and liver function were normal (as shown in table 1). In view of the goitre, his thyroid function test was tested and reveals subclinical hyperthyroidism with the thyroid-stimulating hormone level of $0.30 \mathrm{IU} / \mathrm{mL}$ (normal range: $0.5-4.95 \mathrm{IU} /$ $\mathrm{mL}$ ), free $\mathrm{T} 4$ level of $17.05 \mathrm{pmol} / \mathrm{L}$ (normal range: $9-19 \mathrm{pmol} / \mathrm{L}$ ) and free T3 level of $1.28 \mathrm{nmol} / \mathrm{L}$ (normal range: $1.08-4.14 \mathrm{nmol} / \mathrm{L}$ ). The ECG shows sinus rhythm with no prolonged QT interval, no U-wave and no acute ischaemic changes.

He was diagnosed with acute lower limb paralysis secondary to hypokalaemia and was treated with $2 \mathrm{~g}$ of potassium chloride in $200 \mathrm{~mL}$ of $0.9 \%$ saline via intravenous infusion over 2 hours. His muscle power improves, and the repeated serum potassium level was $2.9 \mathrm{mmol} / \mathrm{L}$. He was then started on oral potassium chloride $1.2 \mathrm{~g}$ three times per day thereafter. Throughout his admission, his potassium level was persistently below $3.0 \mathrm{mmol} / \mathrm{L}$ despite on oral potassium supplements. His 24-hour urine potassium was normal $(12 \mathrm{mEq} / 24$ hours, normal range: $<15 \mathrm{mEq} / 24$ hours). A CT scan of the neck and thorax was done and showed diffuse goitre with a retrosternal extension over the right side (as shown in figures 1 and 2). He was subjected to ultrasoundguided fine-needle aspiration for cytology of the thyroid, which reveals cystic contain with no malignant cells. His anti-thyroglobulin antibody was negative. In view of persistent hypokalaemia despite taking regular oral potassium replacement with the background of normal blood $\mathrm{pH}$ and urine potassium level, HPP secondary to subclinical hyperthyroidism was suspected. 


\begin{tabular}{lll}
\hline $\begin{array}{l}\text { Table } 1 \text { Laboratory investigations which were done throughout } \\
\text { hospitalisation period }\end{array}$ & \\
\hline Blood investigations & Results & Normal range \\
\hline Haemoglobin & $124 \mathrm{~g} / \mathrm{L}$ & $120-180 \mathrm{~g} / \mathrm{L}$ \\
\hline Platelet & $266 \times 10^{9} / \mathrm{L}$ & $150-400 \times 10^{9} / \mathrm{L}$ \\
\hline White cell count & $10.2 \times 10^{9} / \mathrm{L}$ & $4.0-11.0 \times 10^{9} / \mathrm{L}$ \\
\hline Albumin & $38 \mathrm{~g} / \mathrm{L}$ & $35-50 \mathrm{~g} / \mathrm{L}$ \\
\hline Alkaline phosphatase & $63 \mathrm{U} / \mathrm{L}$ & $50-150 \mathrm{U} / \mathrm{L}$ \\
\hline Alanine transaminase & $29 \mathrm{U} / \mathrm{L}$ & $5-35 \mathrm{U} / \mathrm{L}$ \\
\hline Random blood sugar & $7.2 \mathrm{mmol} / \mathrm{L}$ & $<11.1 \mathrm{mmol} / \mathrm{L}$ \\
\hline Creatinine & $118 \mu \mathrm{mol} / \mathrm{L}$ & $60-120 \mu \mathrm{mol} / \mathrm{L}$ \\
\hline Sodium & $136 \mathrm{mmol} / \mathrm{L}$ & $135-150 \mathrm{mmol} / \mathrm{L}$ \\
\hline Potassium & $2.2 \mathrm{mmol} / \mathrm{L}$ & $3.5-5.0 \mathrm{mmol} / \mathrm{L}$ \\
\hline Urea & $5.2 \mathrm{mmol} / \mathrm{L}$ & $1.7-8.0 \mathrm{mmol} / \mathrm{L}$ \\
\hline Magnesium & $1.2 \mathrm{mmol} / \mathrm{L}$ & $0.66-1.07 \mathrm{mmol} / \mathrm{L}$ \\
\hline Corrected calcium & $2.44 \mathrm{mmol} / \mathrm{L}$ & $2.15-2.55 \mathrm{mmol} / \mathrm{L}$ \\
\hline Phosphate & $1.06 \mathrm{mmol} / \mathrm{L}$ & $0.75-1.50 \mathrm{mmol} / \mathrm{L}$ \\
\hline Blood pH & 7.38 & $7.35-7.45$ \\
\hline Bicarbonate & $26 \mathrm{mmol} / \mathrm{L}$ & $21-28 \mathrm{mmol} / \mathrm{L}$ \\
\hline Thyroid-stimulating hormone & $0.30 \mathrm{IU} / \mathrm{mL}$ & $0.5-4.95 \mathrm{IU} / \mathrm{mL}$ \\
\hline Free T4 & $17.05 \mathrm{pmol} / \mathrm{L}$ & $9-19 \mathrm{pmol} / \mathrm{L}$ \\
\hline Free T3 & $1.28 \mathrm{nmol} / \mathrm{L}$ & $1.08-4.14 \mathrm{nmol} / \mathrm{L}$ \\
\hline Anti-thyroglobulin antibody & $<10 \mathrm{IU} / \mathrm{mL}$ & $0-115 \mathrm{IU} / \mathrm{mL}$ \\
\hline Early morning serum cortisol & $380 \mathrm{nmol} / \mathrm{L}$ & $101.2-530 \mathrm{nmol} / \mathrm{L}$ \\
\hline $24-$ hour urine potassium & $12 \mathrm{mmol} / 24 \mathrm{hours}$ & $<15 \mathrm{mmol} / 24 \mathrm{hours}$ \\
\hline T3, & & \\
\hline & & \\
\hline
\end{tabular}

$\mathrm{T}$, triiodothyronine; $\mathrm{T} 4$, thyroxine

\section{INVESTIGATIONS}

Table 1 showed laboratory investigations which revealed severe hypokalaemia in the background of normal other serum electrolyte and blood $\mathrm{pH}$ level. His random blood glucose level, and renal and liver function test were normal. The early morning serum cortisol level was sufficient and the 24-hour urine potassium level was within normal range. His thyroid function level showed subnormal thyroid-stimulating hormone with normal T4 and T3 level, which

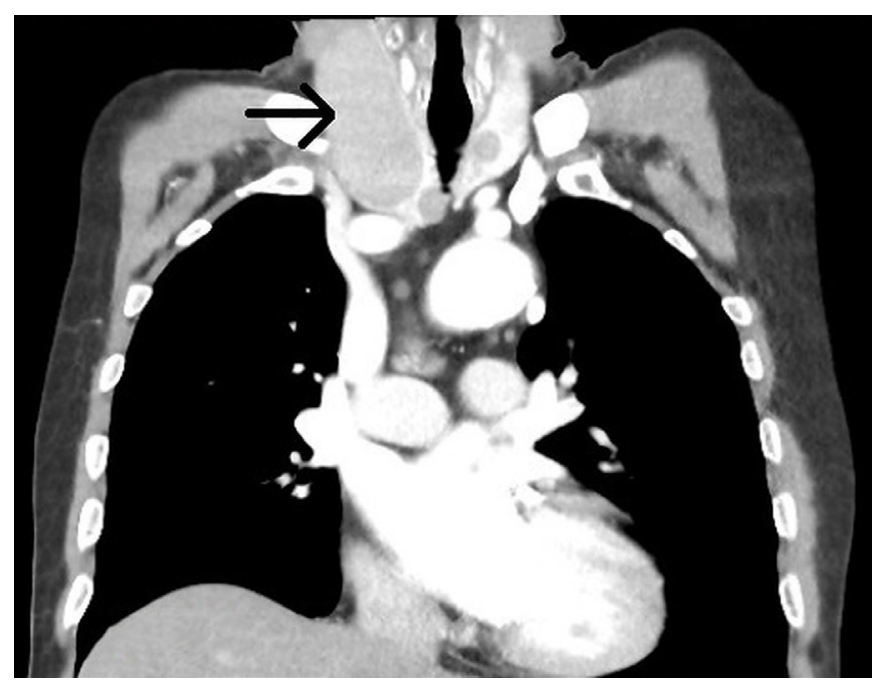

Figure 1 Coronal view of CT scan of the neck and thorax on mediastinal (soft tissue) window which showed diffuse thyroid gland enlargement, right side more than the left with retrosternal extension of the right lobe (as pointed by arrow). There are multiple hypodense nodules within both lobes and isthmus. The trachea is slightly displaced to left with $1.9 \mathrm{~cm}$ focal narrowing at the level of T1 vertebra, with the narrowest internal diameter of $0.7 \mathrm{~cm}$. No cervical lymphadenopathy noted.

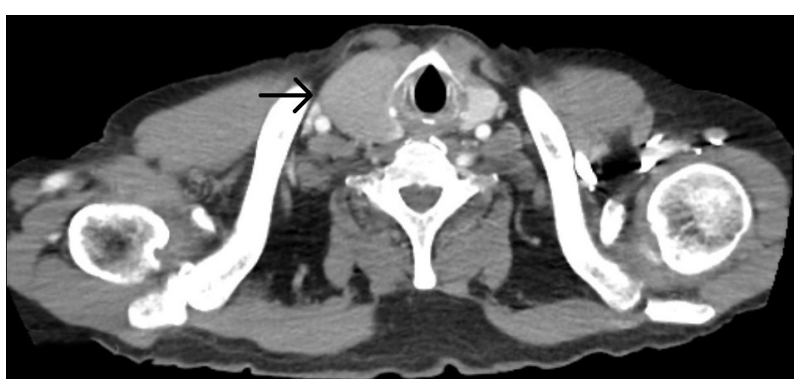

Figure 2 Transverse view of CT scan of the neck which showed enlarged thyroid gland with right side more than left. The largest nodule is within right lobe with enhancing solid component, measuring $4.4 \times 4.2 \times 7.5 \mathrm{~cm}$ (as pointed by arrow). No internal septation or calcification.

signifies subclinical hyperthyroidism. The anti-thyroglobulin antibody level was negative.

\section{DIFFERENTIAL DIAGNOSIS}

In general, hypokalaemia can be caused by reduced intake, increased transcellular shift, and increased losses via the urinary or gastrointestinal tract, or through excessive sweating. In this case, the patient did not have any diarrhoea, no profuse sweating and was not taking any medicine that can increase potassium excretion. The hypokalaemia episode was persistent below $3.0 \mathrm{mmol} / \mathrm{L}$ despite rapid potassium replacement therapy via intravenous infusion, and followed by oral replacement. His 24-hour urinary potassium was within normal range, which excluded renal losses. Therefore, rapid intracellular shift of potassium causing hypokalaemia was suspected. He was not on any medication such as beta-agonist or insulin that increases the potassium transcellular shift. He has no preceding history of taking high amount of carbohydrate-contained diet nor drinks alcohol-contained beverages. Therefore, although he was clinically euthyroid and his thyroid level was normal, there is a possibility that the transcellular shift of potassium leading to hypokalaemia was due to subclinical hyperthyroidism. He responded to the anti-thyroid medication and non-selective beta-blockers, and managed to maintain the potassium within normal range without any further episode of lower limb weakness.

\section{TREATMENT}

He was started on oral carbimazole $5 \mathrm{mg}$ once daily and oral propranolol $20 \mathrm{mg}$ two times per day. He was also given oral potassium supplement in the form of oral potassium chloride $1.2 \mathrm{~g}$ three times per day.

He was also referred to general and cardiothoracic surgery for further management of his huge goitre with retrosternal extension.

\section{OUTCOME AND FOLLOW-UP}

He was initially followed up under local health clinic to monitor his serum potassium level, which was within normal range. He is currently under regular endocrine clinic follow-up every 3 months. His thyroid-stimulating hormone level was normal and stable since then, and there is no further episode of muscle weakness.

\section{DISCUSSION}

HPP is a clinical condition characterised by a recurrent episode of acute muscle paralysis, which commonly involves the lower limb that occurs in the background of hypokalaemia. It can be divided into two forms, which are familial and sporadic HPP. Familial HPP is inherited in an autosomal dominant pattern and is more 
common among the Caucasian population. On the other hand, sporadic HPP is more common among Asian populations and can be linked to a number of causes, including hyperthyroidism, renal tubular acidosis, Gitelman syndrome, primary hyperaldosteronism, barium poisoning and many others. HPP secondary to hyperthyroidism is the most common cause of sporadic HPP. ${ }^{1}$ It is more common in men at the age of $20-40$ years old. It can be precipitated by strenuous exercises, a high-carbohydrate diet, emotional stress and certain drugs like steroids. ${ }^{2}$ The exact mechanism on how hyperthyroidism can cause HPP is not well understood. One plausible proposed explanation is that T4 promotes sodium/ potassium ATPase-mediated cellular uptake of potassium ions. ${ }^{2}$ Therefore, a high level of T4 will cause a rapid and massive intracellular shift of potassium leading to extracellular hypokalaemia. Apart from that, androgens may also play a significant role in the pathophysiology, where it increases the expression and activity of the $\mathrm{Na}+/ \mathrm{K}+$-ATPase. ${ }^{3}$ This may explain why HPP secondary to hyperthyroidism is higher in men, even though hyperthyroidism is far more common in women. ${ }^{4}$

In this report, our patient developed HPP in the background of subclinical hyperthyroidism. It is a condition where clinically asymptomatic, and biochemically normal T4 level in the background of subnormal level of thyroid-stimulating hormone. There are very few similar cases reported in the literature. Hegde et $a l^{5}$ reported a young man with a family history of thyroid disorder who developed HPP in the background of subclinical hyperthyroidism. On

\section{Patient's perspective}

As a result of difficulty to walk from the lower limb weakness, I faced a very difficult time since I am staying alone in a 3rd story apartment, and my work mainly involves travelling. My family and I feel relieved that my condition improved.

\section{Learning points}

- Although hypokalaemic periodic paralysis is more common in hyperthyroidism, this case report showed that it can also occur in subclinical hyperthyroidism.

- A very high index of suspicion is needed among any treating physicians to diagnose this condition. This is because even in a patient with hyperthyroidism, the thyrotoxic symptoms can be absent during hypokalaemic periodic paralysis attack in $10 \%-25 \%$ of the patients. This makes the diagnosis very challenging, more than it already has.

- Treatment of hypokalaemic periodic paralysis secondary to hyperthyroidism involves prompt potassium replacement via oral or intravenous route depending on the level of potassium deficit and also the severity of weakness.

- It is important to remember that rebound hyperkalaemia can occur during the replacement period, and fatal cardiac arrhythmias have been reported as a result of it. Therefore, serum potassium has to be closely monitored during the treatment.

- Apart from potassium replacement, it is necessary to start on non-selective beta-blockers and anti-thyroid medication in this condition in order to prevent further episode of recurrent hypokalaemic periodic paralysis, even in subclinical hyperthyroidism. further investigation, he was found to have Graves' disease, which is commonly seen in a patient with HPP. This is further supported by Rajpal and Sood ${ }^{6}$ who have reported another case of HPP that developed in a patient with Graves' disease who remained clinically and biochemically euthyroid. In the article, the authors even suggested to consider patients with Graves' disease to be one of the possible causes of HPP despite being euthyroid. Verma $\mathrm{et}_{\mathrm{al}} \mathrm{l}^{7}$ who studied 15 patients with hyperthyroidism who developed HPP also reported a patient with subclinical hyperthyroidism. The diagnosis of HPP in subclinical hyperthyroidism requires a very high index of suspicion by the clinician. This is because even in patients with biochemical hyperthyroidism, 10\%-25\% of the patients have no clinical symptoms of hyperthyroidism during the paralytic attack. ${ }^{6}$ Unlike the patients discussed in the previous case reports, our patient is unique as he is from an older age group and has no family history of thyroid disease. His anti-thyroglobulin antibody was also negative. Therefore, we believe this report will add to the rare presentation of HPP in subclinical hyperthyroidism. The treatment of HPP secondary to hyperthyroidism involves prompt replacement of potassium via oral or intravenous route depending on the level of potassium deficit and also the severity of weakness. ${ }^{13-7}$ There is a risk of rebound hyperkalaemia during the replacement period and can potentially cause fatal cardiac arrhythmias. ${ }^{5} 6$ Therefore, serum potassium needs to be monitored closely during the treatment. Non-selective beta-blockers and anti-thyroid medication are also used to treat this clinical condition, which prevent recurrent episodes of hypokalaemia from high intracellular shift of potassium.

Acknowledgements The authors would like to thank the patient for giving his consent and cooperation in relation to the writing of this case report. The authors would also like to thank the director general of the Ministry of Health of Malaysia for his permission to publish this article.

Contributors AOP—writing, editing and correspondence. SLL—writing and editing. NT—collecting data and reviewing. NM—reviewing, final editing and supervising.

Funding The authors have not declared a specific grant for this research from any funding agency in the public, commercial or not-for-profit sectors.

Competing interests None declared.

Patient consent for publication Obtained.

Provenance and peer review Not commissioned; externally peer reviewed.

Open access This is an open access article distributed in accordance with the Creative Commons Attribution Non Commercial (CC BY-NC 4.0) license, which permits others to distribute, remix, adapt, build upon this work non-commercially, and license their derivative works on different terms, provided the original work is properly cited and the use is non-commercial. See: http://creativecommons.org/ licenses/by-nc/4.0/

\section{ORCID iD}

Alvin Oliver Payus http://orcid.org/0000-0003-4675-103X

\section{REFERENCES}

1 Vijayakumar A, Ashwath G, Thimmappa D. Thyrotoxic periodic paralysis: clinical challenges. J Thyroid Res 2014;2014:1-6.

2 Kasper D, Fauci A, Hauser S. Harrison's principles of internal medicine. 19 edn. Mcgrawhill, 2015

3 Wi J-K, Lee HJ, Kim EY, et al. Etiology of hypokalemic paralysis in Korea: data from a single center. Electrolyte Blood Press 2012;10:18-25.

4 Kalita J, Goyal G, Bhoi SK, et al. Comparative study of thyrotoxic periodic paralysis from idiopathic hypokalemic periodic paralysis: an experience from India. Ann Indian Acad Neurol 2012;15:186.

5 Hegde S, Shaikh MA, Gummadi T. Hypokalaemic periodic paralysis in a patient with subclinical hyperthyroidism: a rare case. J Clin Diagn Res 2016;10:0D14.

6 Rajpal A, Sood A. Hypokalemic periodic paralysis in a patient with euthyroid Graves disease and celiac disease. AACE Clin Case Rep 2019;5:e73-6.

7 Verma V, Kumar Y, Kotwal N, et al. Thyrotoxic periodic paralysis: a retrospective, observational study from India. Indian J Med Res 2020;151:42. 
Copyright 2021 BMJ Publishing Group. All rights reserved. For permission to reuse any of this content visit https://www.bmj.com/company/products-services/rights-and-licensing/permissions/

BMJ Case Report Fellows may re-use this article for personal use and teaching without any further permission.

Become a Fellow of BMJ Case Reports today and you can:

- Submit as many cases as you like

- Enjoy fast sympathetic peer review and rapid publication of accepted articles

- Access all the published articles

Re-use any of the published material for personal use and teaching without further permission

Customer Service

If you have any further queries about your subscription, please contact our customer services team on +44 (0) 2071111105 or via email at support@bmj.com.

Visit casereports.bmj.com for more articles like this and to become a Fellow 